\title{
Total body and exchangeable potassium in chronic airways obstruction: a controversial area?
}

\author{
KEITH BODDY ${ }^{1}$, D. L. DAVIES ${ }^{2}$, A. D. HOWIE ${ }^{3}$, M. MONIR MADKOUR ${ }^{3}$, \\ MAUREEN E. MAHAFFY ${ }^{1}$, AND A. I. PACK ${ }^{3}$
}

From the Health Physics and Nuclear Medicine Unit ${ }^{1}$, Scottish Universities Research and Reactor Centre, East Kilbride, Glasgow, the Department of Medicine ${ }^{2}$, Western Infirmary, Glasgow, and the Centre for Respiratory Diseases", Royal Infirmary, Glasgow

Boddy, K., Davies, D. L., Howie, A. D., Monir Madkour, M., Mahaffy, Maureen E., and Pack, A. I. (1978). Thorax, 33, 62-66. Total body and exchangeable potassium in chronic airways obstruction: a controversial area? Potassium deficiency is an important complication in the treatment of heart disease. However, there is a serious dichotomy in the literature. Severe potassium depletion has been reported in this condition when exchangeable potassium was measured whereas normal levels or marginal depletion were found in measurements of total body potassium. To clarify this situation, simultaneous measurements of total body potassium by whole-body counting, and of exchangeable potassium by isotope dilution using ${ }^{43} \mathrm{~K}$, were made in 10 male subjects with established airways obstruction. Sequential determinations showed that exchangeable potassium increased up to 68 hours after administration, and values obtained at only 24 hours would have been a substantial underestimate. In this group of subjects neither total body nor exchangeable potassium at 48 hours was significantly different from the expected normal value.

We have previously reported (Howie et al., 1976) normal values of total body potassium (TBK) in a group of patients with chronic cor pulmonale, contrasting with earlier studies in which exchangeable body potassium $\left(\mathrm{K}_{\mathrm{e}}\right)$ showed gross potassium depletion (Baum et al., 1959; Bauer et al., 1966; Telfer et al., 1968, 1975; Schloerb et al., 1970; Campbell et al., 1975). It was pointed out (Howie et al., 1976) that the apparent conflict in these findings was reconcilable if equilibration between the administered radioactive potassium and native potassium was delayed or if $\mathrm{K}_{e}$ was an unusually small fraction of TBK in this condition. This explanation has been investigated by measuring $K_{e}$ and TBK simultaneously.

\section{Material and methods}

Ten male subjects were included in the study, each having established airways obstruction, judged from spirometric testing, and chronic bronchitis according to the Medical Research Council questionnaire of respiratory symptoms. Relevant physical and clinical details are summarised in Table 1. All patients had previously had at least one episode of acute respiratory failure com-证 plicated by raised jugular venous pressure and peripheral oedema, but at the time of the study응 they were in a chronic compensated state of their respiratory disease and free from oedema. No sub-io ject had a blood urea greater than $10 \mathrm{mmol} / \mathrm{l} 3$. $(60 \mathrm{mg} / 100 \mathrm{ml})$. Drug therapy was discontinued $ᄋ$ 72 hours before the study, at which time all patients were active, ambulant, and taking theiro usual unrestricted diet and fluid intake.

Blood for blood gas estimation was obtainedo from an indwelling cannula inserted into the $\frac{N}{N}$. brachial artery. Each patient was rested in theos sitting position for at least 15 minutes. TwoN arterial samples were taken at 30-minute intervals N to ensure that stable results were obtained. The ${ }_{\sigma}^{\omega}$ blood gases were analysed using an Instrumentation Laboratory blood gas analyser (Model 313).

Total body potassium was measured using the MERLIN mobile whole-body counter (Boddy, 1967) to detect the $1.46 \mathrm{MeV}$ gamma rays from ${ }_{0}^{-}$ the naturally occurring radionuclide ${ }^{40} \mathrm{~K}$, which is a constant fraction of TBK. The counter uses a $\mathrm{NaI}$ detector, $29.2 \mathrm{~cm}$ diameter and $10.2 \mathrm{~cm}$ thick, housed in a lead shadow-shield. The patient, lying? 
Table 1 Clinical features of patients included in study

\begin{tabular}{|c|c|c|c|c|c|c|c|}
\hline Patient & $\begin{array}{l}\text { Age } \\
\text { (years) }\end{array}$ & $\begin{array}{l}\text { Height } \\
(\mathrm{cm})\end{array}$ & $\begin{array}{l}\text { Weight } \\
(\text { kg) }\end{array}$ & Drug therapy ${ }^{1}$ & $\begin{array}{l}\text { Duration of } \\
\text { diuretic } \\
\text { therapy } \\
\text { (years) }\end{array}$ & $\begin{array}{l}\text { FVC } \\
\text { (litres) }\end{array}$ & $\begin{array}{l}F E V_{1} \\
\text { (litres) }\end{array}$ \\
\hline 1 & 76 & $167 \cdot 6$ & 73.9 & $\begin{array}{l}\text { Frusemide, } 40 \mathrm{mg} \text { daily } \\
\text { Slow } \mathrm{K}, 600 \mathrm{mg} \text { tid } \\
\text { Salbutamol, } 4 \mathrm{mg} \text { tid }\end{array}$ & 3 & 1.78 & 0.56 \\
\hline 2 & 60 & $162 \cdot 6$ & $50 \cdot 3$ & $\begin{array}{l}\text { Frusemide, } 40 \mathrm{mg} \text { daily } \\
\text { Slow } \mathrm{K}, 600 \mathrm{mg} \text { bd }\end{array}$ & 5 & $1 \cdot 52$ & 0.46 \\
\hline 3 & 63 & $162 \cdot 6$ & $60 \cdot 3$ & Nil & & $1 \cdot 85$ & 0.92 \\
\hline 4 & 70 & $170 \cdot 2$ & $85 \cdot 7$ & Nil & & $2 \cdot 74$ & 1.52 \\
\hline 5 & 47 & 175.0 & $77 \cdot 7$ & Nil & & 2.94 & 1.81 \\
\hline 6 & 76 & $161 \cdot 3$ & $44 \cdot 0$ & $\begin{array}{l}\text { Frusemide, } 40 \mathrm{mg} \text { daily } \\
\text { Slow } \mathrm{K}, 600 \mathrm{mg} \text { tid } \\
\text { Salbutamol inhaler }\end{array}$ & 1 & $1 \cdot 65$ & 0.89 \\
\hline 7 & 67 & $165 \cdot 1$ & $65 \cdot 8$ & $\begin{array}{l}\text { Frusemide, } 40 \mathrm{mg} \text { daily } \\
\text { Slow } \mathrm{K}, 600 \mathrm{mg} \text { bd } \\
\text { Salbutamol inhaler }\end{array}$ & 7 & $2 \cdot 13$ & 0.89 \\
\hline 8 & 68 & $165 \cdot 1$ & $65 \cdot 8$ & $\begin{array}{l}\text { Frusemide, } 40 \mathrm{mg} \text { daily } \\
\text { Slow } \mathrm{K}, 600 \mathrm{mg} \text { bd } \\
\text { Salbutamol, } 4 \mathrm{mg} \text { qid } \\
\text { Digoxin }\end{array}$ & 3 & 1.85 & 0.71 \\
\hline 9 & 71 & $168 \cdot 0$ & $56 \cdot 8$ & $\begin{array}{l}\text { Frusemide, } 40 \mathrm{mg} \text { daily } \\
\text { Slow } \mathrm{K}, 600 \mathrm{mg} \text { tid }\end{array}$ & 4 & 1.22 & 0.50 \\
\hline 10 & 53 & 165.0 & $82 \cdot 7$ & $\begin{array}{l}\text { Frusemide, } 80 \mathrm{mg} \text { daily } \\
\text { Slow } \mathrm{K}, 600 \mathrm{mg} \text { tid } \\
\text { Salbutamol inhaler }\end{array}$ & 2 & 3.04 & 1.53 \\
\hline
\end{tabular}

${ }^{1}$ All drug therapy discontinued 72 hours before study

on a motorised couch, passes beneath the detector in the supine and then the prone position. For an average male, the method has a standard error of less than $4 \%$. The procedure has been described in detail previously (Boddy et al., 1971). The measured TBK in each subject was compared with the expected normal values and range estimated from height and age and from height, weight, and age (Boddy et al., 1972).

Exchangeable body potassium was measured by the general method of Davies and Robertson (1973) except that ${ }^{43} \mathrm{~K}$ alone was administered. Samples were taken at 20,44 , and 68 hours after the oral administration of $40 \mu \mathrm{Ci}$ of ${ }^{43} \mathrm{~K}$. Three separate 'spot' urine samples were taken after each equilibration period, which was preceded by a 12-hour overnight fast. The potassium content of the samples was measured using a Technicon Mark III flame photometer. Potassium-43 was measured in duplicated $10-\mathrm{ml}$ aliquots using a Packard 5330 automatic gamma spectrometer.

\section{Results}

Blood gas and plasma electrolyte measurements are summarised in Table 2 , showing hypoxaemia in all subjects $\left(\mathrm{PaO}_{2}<10.3 \mathrm{kPa}\right)$. The arterial carbon dioxide tension $\left(\mathrm{PaCO}_{2}\right)$ was frequently increased, but in all patients the plasma potassium was within normal limits.
Table 2 Measurements of arterial blood gases and electrolytes

\begin{tabular}{|c|c|c|c|c|c|c|c|c|}
\hline \multirow[b]{2}{*}{ Patient } & \multirow[b]{2}{*}{$p H$} & \multirow{2}{*}{$\begin{array}{l}\mathrm{PaO}_{2} \\
(\mathrm{kPa})\end{array}$} & \multirow{2}{*}{$\begin{array}{l}\mathrm{PaCO}_{2} \\
(\mathrm{kPa})\end{array}$} & \multicolumn{5}{|c|}{ Plasma electrolytes (mmoles/l) } \\
\hline & & & & $K$ & $\mathrm{Na}$ & $\mathrm{Cl}$ & $\mathrm{HCO}_{2}$ & Urea \\
\hline 1 & $7 \cdot 42$ & $9 \cdot 40$ & $4 \cdot 54$ & $4 \cdot 0$ & 139 & 104 & 27 & $7 \cdot 2$ \\
\hline 2 & $7 \cdot 4$ & & $6 \cdot c$ & 3.9 & 13 & 98 & 28 & $6 \cdot 2$ \\
\hline 3 & $7 \cdot 4$ & 9. & $5 \cdot 2$ & 4.4 & 1 & 101 & 27 & $5 \cdot 3$ \\
\hline 4 & $7 \cdot 46$ & 8.51 & $4 \cdot 40$ & $3 \cdot 8$ & 135 & 97 & 29 & $5 \cdot 6$ \\
\hline 5 & $7 \cdot 41$ & & & 3.4 & 1 & 97 & 27 & $4 \cdot 7$ \\
\hline 6 & $7 \cdot 43$ & $8 \cdot 78$ & $4 \cdot 88$ & $4 \cdot 0$ & 138 & 102 & 29 & 6.7 \\
\hline 7 & $7 \cdot 42$ & & $5 \cdot 61$ & $4 \cdot 2$ & 137 & 101 & 26 & $7 \cdot 0$ \\
\hline 8 & $7 \cdot 40$ & $10 \cdot 32$ & 5. & $4 \cdot 1$ & 138 & 103 & 25 & $7 \cdot 4$ \\
\hline 9 & $7 \cdot 35$ & 9. & 6.8 & 4. & 139 & 99 & 31 & $8 \cdot 1$ \\
\hline 10 & $7 \cdot 44$ & 9.58 & $5 \cdot 64$ & 3.8 & 136 & 100 & 23 & $5 \cdot 2$ \\
\hline
\end{tabular}

Conversion: SI to traditional units-Potassium: $1 \mathrm{mmol} / 1 \approx 1 \mathrm{mEq} / \mathrm{l}$. Sodium: $1 \mathrm{mmol} / \mathrm{l} \approx 1 \mathrm{mEq} / \mathrm{l}$. Chlorine: $1 \mathrm{mmol} / 1 \approx 1 \mathrm{mEq} / \mathrm{l}$. Bicarbonate: $1 \mathrm{mmol} / 1 \approx 1 \mathrm{mEq} / \mathrm{l}$. Urea: $1 \mathrm{mmol} / 1 \approx 6 \mathrm{mg} / 100 \mathrm{ml}$.

The observed and expected normal values of TBK are given in Table 3 . The measured TBK was not significantly different from the expected normal values based on height, weight, and age, with the exception of subject 5 , whose measured value was significantly greater than that expected $(\mathrm{P}<0.05)$. In comparison with the expected values based on height and age, the measured value of TBK in subject 5 was again significantly greater $(P<0.01)$, and in subjects 6 and 9 they were significantly lower $(P<0.05)$. In the group as a whole, the measured TBK was not significantly different 
Table 3 Measured and predicted values of $K_{e}$ and $T B K$

\begin{tabular}{|c|c|c|c|c|c|c|c|c|}
\hline \multirow[b]{2}{*}{ Patient } & \multicolumn{3}{|c|}{$K_{e}(\mathrm{mmol})$ measured } & \multicolumn{2}{|c|}{$K_{e}$ estimated } & \multirow{2}{*}{$\frac{T B K(\mathrm{mmol})}{\text { Measured }}$} & \multicolumn{2}{|c|}{ TBK estimated } \\
\hline & $20 h$ & $44 h$ & $68 h$ & Moore & Skrabal & & $H t, W t, A g e$ & $H t$, Age \\
\hline 1 & 2452 & 2614 & 2693 & 2733 & 2666 & 2726 & 2982 & 2841 \\
\hline 2 & 1632 & 1983 & 2120 & 2702 & 2212 & 2450 & 2435 & 2731 \\
\hline 3 & 2662 & 2864 & 2943 & 2363 & 2406 & 3110 & 2637 & 2701 \\
\hline 4 & 2994 & 3352 & 3411 & 3054 & 3063 & 3604 & 3430 & 3036 \\
\hline 5 & 3317 & 3774 & 3954 & 3421 & 3254 & 4206 & $3683^{1}$ & $3517^{1}$ \\
\hline 6 & 1216 & 1512 & 1528 & 1920 & 1849 & 1774 & 2043 & $2506^{1}$ \\
\hline 7 & 2355 & 2569 & 2679 & 2513 & 2536 & 3008 & 2808 & 2795 \\
\hline 8 & 2718 & 2843 & 2912 & 2513 & 2524 & 3105 & 2795 & 2785 \\
\hline 9 & 1615 & 1841 & 1936 & 2268 & 2341 & 2123 & 2647 & $2910^{1}$ \\
\hline 10 & 2834 & 3297 & 3419 & 3573 & 3112 & 3579 & 3402 & 2932 \\
\hline Mean & $2379 \cdot 5$ & $2664 \cdot 9$ & $2759 \cdot 5$ & $2706 \cdot 0$ & $2596 \cdot 3$ & $2965 \cdot 5$ & $2886 \cdot 2$ & $2875 \cdot 4$ \\
\hline SD & 679.9 & $719 \cdot 4$ & $742 \cdot 2$ & 514.9 & $439 \cdot 4$ & $737 \cdot 1$ & $500 \cdot 5$ & $267 \cdot 8$ \\
\hline SE & $215 \cdot 0$ & $227 \cdot 5$ & $234 \cdot 7$ & $162 \cdot 8$ & 138.9 & $233 \cdot 1$ & $158 \cdot 3$ & $\varepsilon 4 \cdot 7$ \\
\hline
\end{tabular}

${ }^{1}$ Measured TBK significantly different from predicted value.

from the expected values $(\mathrm{P}>0 \cdot 10$, Wilcoxon's signed ranks test).

As shown in the Figure, $\mathrm{K}_{\mathrm{e}}$ increased progressively in all subjects up to 68 hours postadministration. The values obtained (Table 3 ) at 20 hours were significantly lower $(\mathrm{P}<0.002)$ than those at $\mathbf{4 4}$ hours, which in turn were significantly lower $(\mathrm{P}<0.002)$ than those at 68 hours (Wilcoxon's signed ranks test). The respective mean values $( \pm \mathrm{SE})$ were $2380 \pm 215 \mathrm{mmol} \mathrm{K}, 2665 \pm$ $228 \mathrm{mmol} \mathrm{K}$, and $2760 \pm 235 \mathrm{mmol} \mathrm{K}$. In all subjects, exchangeable potassium at 68 hours was $92.9 \pm 1.3 \%$ (mean \pm SE) of TBK, $101 \cdot 2 \pm 5 \cdot 1 \%$ of

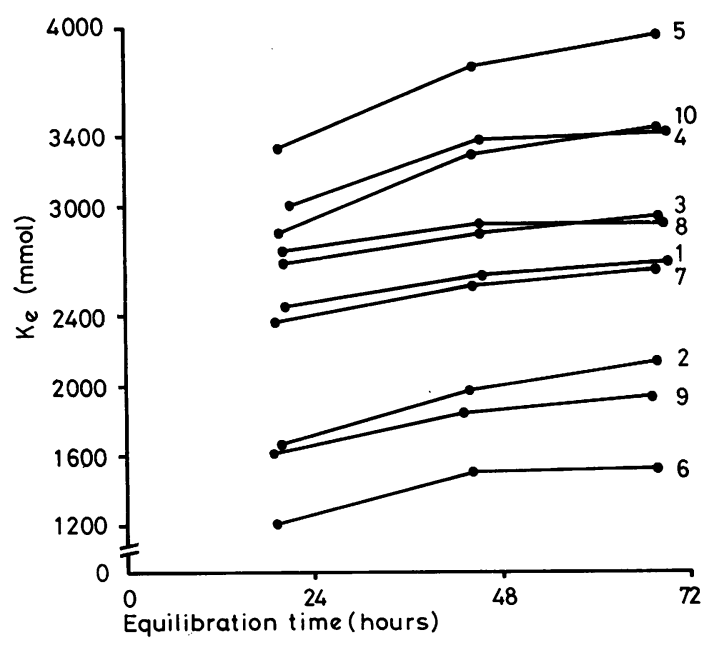

Figure Exchangeable potassium values are shown for each patient (identified by case number) as measured at various equilibration times. Equilibration is not complete even at 48 hours post-administration, and values obtained after only 24 hours substantially underestimate $K_{e}$. the expected normal values using the equations of Moore et al. (1963) and 104.8 $\pm 4.5 \%$ using the data of Skrabel et al. (1973).

\section{Discussion}

The present study confirms our previous findings (Howie et al., 1976) of normal TBK in a group of subjects with cor pulmonale and, in addition, the value of $\mathrm{K}_{e}$ at 68 hours was not significantly different from the expected normal values (Moore et al., 1963; Skrabel et al., 1973). In no subject was the measured TBK significantly less than both predicted normal values (Boddy et al., 1972). However, in two subjects (6 and 9) the measured value was less than that estimated from height and age only. This could be explained by the comparatively low body weight relative to the height of these subjects, and the measured $\mathrm{K}_{\mathrm{e}}$ was also low. If body potassium was low in these two subjects, it might be due indeterminately to the disease or to causes such as loss of lean tissue (bearing in mind their age) or dietary deficiency. Nevertheless, in the group as a whole we did not find evidence of potassium deficiency.

It was clear from the sequential measurements of $\mathrm{K}_{\mathrm{e}}$ that equilibration of the administered radionuclide and native potassium was incomplete at 20 hours, and misleadingly low values for $\mathrm{K}_{\mathbf{e}}$ would be obtained ( $86 \%$ of the value at 68 hours) after this period. This finding confirms that of Telfer and colleagues (1975), who found significantly higher values (an increase of $20 \%$ ) at 48 hours than at 24 hours in similar patients, and suggests that apparent deficiencies of potassium derived from 24-hour values of $\mathrm{K}_{\mathrm{e}}$ (Baum et al., 1959; Bauer et al., 1966; Telfer et al., 1968; Campbell et al., 1975) require cautious interpretation. In the present study, the values at 68 hours were consistently higher than at 44 hours post- 
adminstration but the mean value was only $3-4 \%$ greater.

There remains an unexplained discrepancy between the gross potassium depletion reported (Schloerb et al., 1970; Telfer et al., 1975) at 48 hours after administration of ${ }^{42} \mathrm{~K}$ and our previous (Howie et al., 1976) and present findings. However, it is interesting to note in the study of Telfer et al. (1975) that both the value of $\mathrm{K}_{\mathrm{e}}$ at 48 hours per litre of intracellular water and the volume of intracellular water were normal. Since the greater part of body potassium (about $98 \%$ ) is intracellular, these observations seem to imply that $K_{e}$ should also have been normal. In addition, total body water, which usually correlates closely with the lean body mass and TBK, was normal, and the patients were said to be free from oedema. We have re-examined the data for the individual patients of Telfer et al. (1975) and, for comparison, expressed the 24-hour values of $K_{e}$ as a percentage of that predicted using the relationships of Skrabel et al. (1973). In six patients the measured values were extraordinarily low (less than $56 \%$, mean $48.7 \pm 2.3 \%$ ), and the values for sodium and bromine, in some cases, also appeared anomalous. The discrepancy in the findings might be attributable partly to the more complex multinuclide method used by Telfer et al. (1975) compared with the one we adopted or it might be due to differences in clinical circumstances, including medication.

In the study of Schloerb et al. (1970), in three of the four patients with chronic respiratory failure, in whom $\mathrm{K}_{\mathrm{e}}$ was measured at 42 to 48 hours post-administration, the $\mathrm{K}_{\mathbf{e}}$ per litre of intracellular water was the same as the mean \pm 1 SD found in healthy controls by Telfer and colleagues (1975). Furthermore, these authors (Schloerb et al., 1970) used unspecified relationships of Moore et al. (1963), but, using the equation $\mathrm{K}_{\mathrm{e}}=$ $1383+2623 \mathrm{Wt}$ for males from 31-60 years and $\mathrm{K}_{\mathrm{e}}=723 \pm 27 \cdot 2 \mathrm{Wt}$ for males from 61-90 years taken from the same source (Moore et al., 1963), we obtained different values for predicted $K_{e}$ from those quoted. In this case the predicted mean $( \pm 1 \mathrm{SD})$ for the four patients of $2893 \pm 361 \mathrm{mmol}$ was not significantly different $(P>0.05)$ from the mean measured $\mathrm{K}_{\mathrm{e}}$ of $2451 \pm 803 \mathrm{mmol}$ (paired Student's $t$ test).

It is possible that we have misunderstood or misinterpreted the published data relating to potassium status in chronic respiratory disease and based on exchangeable body measurements. Nevertheless, our findings clearly showed that a 24-hour period of equilibration is inadequate in this condition, and our direct measurements of total body potassium fail to confirm the significant depletions of potassium reported by other workers.

The present findings may be relevant to a recent review (British Medical Journal, 1977), which concluded that potassium depletion was associated with heart failure but cited only evidence based on measurements of $\mathrm{K}_{\mathrm{e}}$. In contrast, our previous direct determination of total body potassium (Lawson et al., 1976) and those of others (Davidson et al., 1976; Delwaide, 1973) indicated that potassium deficiency was not a major problem in this condition. Further investigations are proceeding.

We thank Mr. K. McElroy and Mr. W. Traquair for excellent technical assistance, Mr. J. Proctor for advice on the statistics, Professor $\mathrm{H}$. W. Wilson and Dr. F. Moran for their interest and encouragement, and Dr. R. S. Kennedy for permission to study the patients under his care.

\section{References}

Bauer, F. K., Telfer, N., Herbst, H. H., Austin, R. C., and Hetter, B. (1966). Hyponatremia and increased exchangeable sodium in chronic obstructive lung disease. American Journal of Medical Science, 250, 245-253.

Baum, G. L., Dick, M. M., Blum, A., Kaupe, A., and Carballo, J. (1959). Total body exchangeable potassium and sodium and extracellular fluid in chronic pulmonary insufficiency. American Heart Journal, $58,53-58$.

Boddy, K. (1967). A high sensitivity shadow-shield whole-body monitor with scanning-bed and tilting chair geometries, incorporated in a mobile laboratory. British Journal of Radiology, 40, 631-637.

Boddy, K., King, P. C., Hume, R., and Weyers, E. (1972). The relation of total body potassium to height, weight and age in normal adults. Journal of Clinical Pathology, 25, 512-517.

Boddy, K., King, P. C., Tothill, P., and Strong, J. A. (1971). Measurement of total body potassium with a shadow-shield whole-body counter: calibration and errors. Physics in Medicine and Biology, 16, 275-282.

British Medical Journal (1977). Editorial. Potassium in heart failure. British Medical Journal, 1, 469-470.

Campbell, R. H. A., Brand, H. L., Cox, J. R., and Howard, P. (1975). Body weight and body water in chronic cor pulmonale. Clinical Science and Molecular Medicine, 49, 323-335.

Davidson, C., Burkinshaw, L., McLachlan, M. S. F., and Morgan, D. B. (1976). Effect of long-term diuretic treatment on body-potassium in heart disease. Lancet, 2, 1044-1047.

Davies, D. L., and Robertson, J. W. K. (1973). Simultaneous measurement of total exchangeable potassium and sodium using ${ }^{43} \mathrm{~K}$ and ${ }^{24} \mathrm{Na}$. Metabolism, 22, 133-137. 
Delwaide, P. A. (1973). Body potassium measurements by whole-body counting: screening of patient populations. Journal of Nuclear Medicine, 14, 40-48. Howie, A. D., Pack, A. I., Boddy, K., and Mahaffy, M. (1976). Total body potassium in cor pulmonale. Thorax, 31, 708-712.

Lawson, D. H., Boddy, K., Gray, J. M. B., Mahaffy, M., and Mills, E. (1976). Potassium supplements in patients receiving long-term diuretics for oedema. Quarterly Journal of Medicine, 49, 469-478.

Moore, F. D., Olesen, K. H., McMurray, J. D., Parker, H. V., Ball, M. R., and Boyden, C. M. (1963). The Body Cell Mass and Its Supporting Environment. W. B. Saunders, Philadelphia.

Schloerb, P. R., King, C. R., Kerby, G., and Ruth, W. E. (1970). Potassium depletion in patients with chronic respiratory failure. American Review of Respiratory Disease, 102, 53-59.
Skrabel, F., Arnot, R. N., and Joplin. G. F. (1973). $\stackrel{\vec{F}}{\vec{\rho}}$ Equations for the prediction of normal values for exchangeable sodium, exchangeable potassium, extracellular fluid volume and total body water. British Medical Journal, 2, 37-38.

Telfer, N., Bauer, F. K., Mickey, M. R., and Herbst. H. H. (1968). Body composition in chronic obstruc- के tive pulmonary disease. American Review of Res- $\overrightarrow{0}$ piratory Disease, 98, 640-645.

Telfer, N., Weiner, J. M., and Merrill, Q. (1975). Distribution of sodium and potassium in chronic obstructive pulmonary disease. American Review of Respiratory Disease, 111, 166-176.

Requests for reprints to: Dr. K. Boddy, Health $\overrightarrow{\vec{\sigma}}$ Physics and Nuclear Medicine Unit, Scottish Univer- $)$ sities Research and Reactor Centre, East Kilbride, 은 Glasgow G75 0QU. 